\title{
Early Events During Quiescent Infection Development by Colletotrichum gloeosporioides in Unripe Avocado Fruits
}

\author{
D. Beno-Moualem and D. Prusky
}

Department of Postharvest Science of Fresh Produce, Agricultural Research Organization, The Volcani Center, P.O. Box 6, Bet Dagan 50250, Israel.

Accepted for publication 11 January 2000.

\begin{abstract}
Beno-Moualem, D., and Prusky, D. 2000. Early events during quiescent infection development by Colletotrichum gloeosporioides in unripe avocado fruits. Phytopathology 90:553-559.

Inoculation of avocado pericarp tissue with Colletotrichum gloeosporioides and treatment of avocado cell cultures with the cell wall elicitor of C. gloeosporioides both increased the production of reactive oxygen species (ROS). However, whereas the production of ROS could be detected within minutes in avocado cell suspensions, it was detected only after $2 \mathrm{~h}$ following inoculation of pericarp tissue. Protein kinase inhibitors such as

alanine ammonia lyase (PAL) activity, and epicatechin levels. But, when $\mathrm{H}_{2} \mathrm{O}_{2}$ treatment was applied following staurosporine treatment, PAL activity was no longer induced. The uninduced ROS production in pericarp tissue of freshly harvested, unripe, resistant fruit was twice as high as in ripe, susceptible fruit. Challenge inoculation of resistant fruit further increased the ROS level; however, this increase did not occur in susceptible fruits. The current findings are consistent with the hypothesis that production of ROS is induced by fungal infection of unripe fruits and, consequently, may modulate resistance, resulting in the inhibition of fungal development and quiescence.
\end{abstract} $\mathrm{K}-252 \mathrm{a}$ and staurosporine and the phosphatase inhibitor microcystin-LR inhibited the release of $\mathrm{H}_{2} \mathrm{O}_{2}$ from avocado cell suspensions. When $1 \mathrm{mM}$ $\mathrm{H}_{2} \mathrm{O}_{2}$ was exogenously applied to pericarp tissue, it enhanced ROS, phenyl-
Additional keywords: fruit resistance, preformed resistance.
Colletotrichum gloeosporioides Penz. (teleomorph: Glomerella cingulata (Stoneman) Spauld. et H. Schrenk) attacks unripe avocado fruits in the orchard. Germinated spores produce appressoria that germinate and breach the cuticle, but the resultant subcuticular hyphae become quiescent and do not develop further until fruit is harvested and ripens (38). Significant physiological changes occur in the host fruit that enable activation of the quiescent pathogen. Four mechanisms have been hypothesized to explain the resistance of unripe fruit to fungal attack: (i) lack of nutritional requirements for the pathogen; (ii) presence of preformed antifungal compounds; (iii) presence of inducible antifungal compounds; and (iv) lack of activation of fungal pathogenicity factors.

Resistance of unripe avocado to attack by $C$. gloeosporioides is correlated with the presence of fungitoxic concentrations of the preformed antifungal compound 1-acetoxy-2-hydroxy-4-oxoheneicosa12,15-diene (diene) in the pericarp of unripe fruits (44). Decrease of diene concentration and resultant increased susceptibility has been attributed to the activity of the host-derived enzyme lipoxygenase, which oxidizes the compound (43). The activity of lipoxygenase is regulated by the levels of the flavan-3-ol epicatechin (22), a natural antioxidant present in the pericarp that declines during fruit ripening (43). Increased diene concentration was accompanied by an increase in the transcriptional activation of genes involved in the biosynthesis of the flavonoid epicatechin (2). However, no increase in epicatechin could be induced in ripe fruit (22). Differences in host gene expression during fruit ripening seem to be the rule in the host-pathogen interactions of harvested produce.

The transient and rapid production of reactive oxygen species (ROS) including superoxide, $\mathrm{H}_{2} \mathrm{O}_{2}$, and hydroxyl radical by various elicitors is well documented $(1,3,7,32,34,50,51)$. It is not clear

Corresponding author: D. Prusky; E-mail address: prusky33@netvision.net.il

Publication no. P-2000-0324-01R

(c) 2000 The American Phytopathological Society whether ROS produced in plants in response to a pathogen or elicitor have direct antimicrobial effects (5). But the ROS are considered to be involved in various defensive reactions such as lipid peroxidation $(23,53)$, oxidative cross-linking of cell wall proteins (9), peroxidative polymerization of cinnamoyl alcohol, and reinforcement of plant cell walls by the formation of lignin polymers $(19,24)$, phytoalexin production $(1,13,53)$, and programmed cell death (28). No reports have been published on the importance of ROS in the initial stages of quiescence development in fruits by pathogens during postharvest.

Several reports indicate that ROS synthesis occurs at the extracellular surface of the plasma membrane via a one-electron reduction of molecular oxygen (3). It has been previously reported that the transfer of electrons from a cytosolic electron donor (NADPH) to electron acceptors at the extracellular surface of the plasma membrane may lead to (i) acidification of the cytosol, (ii) alkalinization of the extracellular medium, and (iii) decrease in the plasma membrane potential $(17,18,31,48)$. These changes induced by pathogens and biotic elicitor compounds mediate a variety of early cellular events, including membrane depolarization, and changes in the permeability of the plasma membrane to calcium ions, protons, potassium, and chloride ions (35). All these effects could contribute to transduction and amplification of signals (27).

In this report, we found that infection of avocado fruit by $C$. gloeosporioides or treatment of avocado cell suspensions with cell wall elicitor induced ROS production. Ripe and unripe fruit tissue differ with regard to ROS production in response to pathogen attack. The unripe, resistant fruits are physiologically able to react and produce high levels of ROS that can enhance the phenylpropanoid pathway, regulate the levels of the antifungal compound diene, and inhibit fungal development, resulting in its quiescence (42).

\section{MATERIALS AND METHODS}

Plant material and experimental treatments. Experiments were carried out with freshly harvested avocado fruits (Persea ameri- 
cana Miller var. drymifolia (Schldl. and Cham.) S.F. Blake) cv. Fuerte from an orchard at Kibbutz Givat Brenner, Rehovot, Israel. Experiments were carried out during three consecutive harvesting seasons and repeated at least three times per season. The average value of three to five replications of one single experiment is usually presented. In some cases, the average of all the replications from repeated experiments are presented with their pooled standard error. Fruits of fairly uniform size and weight ( 250 to $270 \mathrm{~g}$ ) were harvested, washed in water, and used 1 to $2 \mathrm{~h}$ after harvest for experiments. Pericarp tissue strips (about $1 \mathrm{~mm}$ thick, almost free of mesocarp tissue) were cut, washed several times with water, and aerated for $20 \mathrm{~h}$ in $0.2 \mathrm{mM} \mathrm{CaSO}_{4}$. The pericarp strips were then placed with the interior side in contact with the filter paper saturated with $0.2 \mathrm{mM} \mathrm{CaSO}_{4}$, and the upper cuticular side was used for fungal inoculation.

Suspension cultures were generated from pericarp callus cultures by transferring $1 \mathrm{~cm}^{3}$ of callus tissue into $40 \mathrm{ml}$ of the medium described by Prusky et al. (44), with the growth regulator picloram at a concentration of $50 \mu \mathrm{g} / \mathrm{liter}$ of medium, without agar, in a $250-\mathrm{ml}$ Erlenmeyer flask. Cells for experiments were grown at room temperature with continuous agitation at $96 \mathrm{rpm}$ on a rotary shaker.

Pericarp inoculation and $\mathrm{H}_{2} \mathrm{O}_{2}$ treatment. A single-spore isolate of C. gloeosporioides isolate Cg-14 (39) was obtained previously from decayed avocado fruits. The fungus was normally maintained on potato dextrose agar at $20^{\circ} \mathrm{C}$. A spore suspension $\left(2 \times 10^{6}\right.$ spores per $\mathrm{ml}$ ) was brushed over pericarp strips (41). In some cases, pericarp strips were also brushed with a freshly prepared solution of $1 \mathrm{mM}$ or $5 \mathrm{mM} \mathrm{H}_{2} \mathrm{O}_{2}$ (E. Merck AG, Darmstadt, Germany). As a control, pericarp strips were brushed with distilled water only. Following inoculation or $\mathrm{H}_{2} \mathrm{O}_{2}$ treatment, plasma membranes were isolated.

Extraction of epicatechin. Epicatechin was extracted from 1-mmthick avocado pericarp, as previously described (39). Three grams (fresh weight) of pericarp was ground in $95 \%$ ethanol (1:10, wt/vol). The ethanol extract was dried in a rotary evaporator, and the residue was redissolved in $10 \mathrm{ml}$ of $1 \mathrm{mM} \mathrm{NaCl}$ and extracted twice with $90 \mathrm{ml}$ of ethyl acetate. Epicatechin was quantitated by reverse phase-high-performance liquid chromatography (HPLC) (RP-18) in a column eluted with 55\% methanol and $1 \%$ acetic acid in doubledistilled water. Calculation of the epicatechin level was based on comparison of the HPLC peak areas quantitated at $275 \mathrm{~nm}$ to those of the standard.

Extraction and activity of phenylalanine ammonia lyase (PAL). Samples for PAL activity were extracted by blending $5 \mathrm{~g}$ of avocado

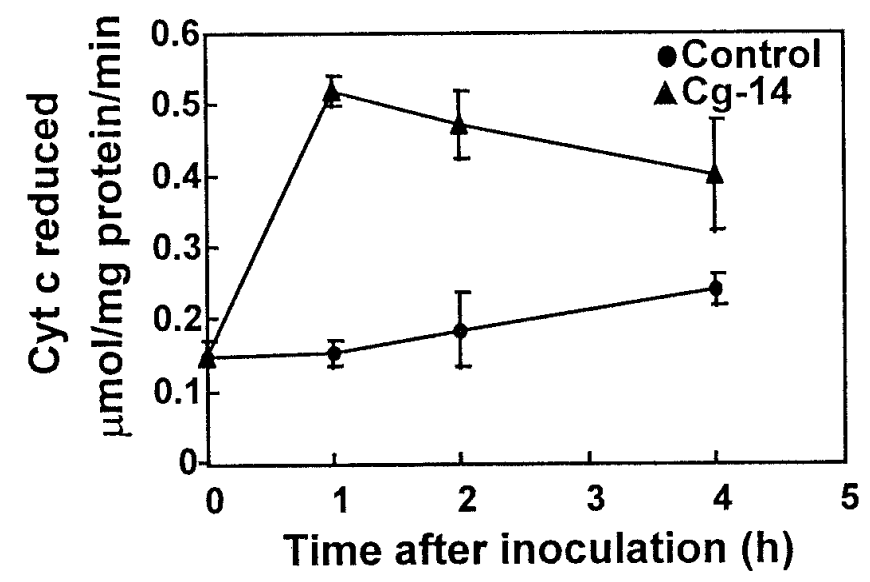

Fig. 1. Time course of reactive oxygen species (ROS) production in plasma membrane isolated from unripe pericarp tissue inoculated with Colletotrichum gloeosporioides strain Cg-14. Bars represent standard error from one representative experiment run four times with five replications. ROS was determined as cytochrome $c$ reduction in the absence and presence of superoxide dismutase according to the method of Owen and Hancock (36). Each molecule of ROS reduces one molecule of cytochrome $c$ (33). pericarp in $50 \mathrm{ml}$ of cold acetone $\left(-20^{\circ} \mathrm{C}\right)$ and the homogenate filtered out with Whatman No. 1 (Whatman International, Ltd., Maidstone, England). This process was carried out four times. The pericarp powder was dried at room temperature overnight and stored at $-20^{\circ} \mathrm{C}$ until use. PAL was extracted from $100 \mathrm{mg}$ of pericarp powder by stirring for $2 \mathrm{~h}$ at $4^{\circ} \mathrm{C}$ with $5 \mathrm{ml}$ of $0.1 \mathrm{M}$ sodium borate buffer, $\mathrm{pH} 8.8$. The extract was centrifuged at $10,000 \times g$ for $20 \mathrm{~min}$ at $4^{\circ} \mathrm{C}$, and the supernatant was used as an enzyme source. The reaction mixture for PAL consisted of $10 \mathrm{mM} \mathrm{L}$-phenylalanine (Aldrich Chemical Co., Milwaukee, WI), $0.1 \mathrm{M}$ borate buffer $(\mathrm{pH}$ 8.8 ), and $1.5 \mathrm{ml}$ of enzyme extract in a final volume of $5 \mathrm{ml}$. The reaction was incubated at $37^{\circ} \mathrm{C}$ for $60 \mathrm{~min}$ and terminated by adding $0.1 \mathrm{ml}$ of $5 \mathrm{~N} \mathrm{HCl}$. The product cinnamic acid was extracted into $7 \mathrm{ml}$ of diethyl ether and quantitated by measuring the amount of trans-cinnamic acid formed at $269 \mathrm{~nm}$ (30).

Elicitor preparation from cell walls of $C$. gloeosporioides. Conidia of $C$. gloeosporioides from single-spore cultures were used to inoculate in Erlenmeyer flasks $(500 \mathrm{ml})$ containing $200 \mathrm{ml}$ of potato dextrose broth. The flasks were incubated at $25^{\circ} \mathrm{C}$ with continuous agitation at $100 \mathrm{rpm}$ for 7 days. Harvesting and disruption of the hyphae were carried out as described by Prusky et al. (39) with glass beads $(0.45$ to $0.5 \mathrm{~mm})$ agitated at maximum speed in a Braun MSK homogenizer (Braun, Melsungen, Germany) for four periods of $45 \mathrm{~s}$ each, with the tube being cooled in ice (6). The broken cell walls were sediments in centrifuge tubes centrifuged at $1,000 \times$ $g$ for $5 \mathrm{~min}$ and washed six times with $50 \mathrm{ml}$ of distilled water. The residual walls were lyophilized, resuspended in distilled water $(10 \mathrm{mg} / \mathrm{ml})$, and autoclaved for $30 \mathrm{~min}$. The autoclaved suspension was centrifuged at $5,000 \times g$ for $10 \mathrm{~min}$ at $4^{\circ} \mathrm{C}$. The supernatant was filtered through a Millipore filter $(0.2 \mu \mathrm{M}$; Gelman Sciences, Ann Arbor, MI), and the collected fraction was evaporated to $2 \%$ of its initial volume. The sample was loaded on a DEAEDiethylaminoethyl Cellulose column (Sigma Chemical Co., St. Louis) washed with $100 \mathrm{ml}$ of $10 \mathrm{mM}$ phosphate buffer at $\mathrm{pH}$ 8.0. The fraction was eluted first with $50 \mathrm{ml}$ of $25 \mathrm{mM}$ phosphate buffer, $\mathrm{pH} 8.0$, and secondly by $50 \mathrm{ml}$ of $500 \mathrm{mM} \mathrm{NaCl}$ (4). Both fractions were pooled, concentrated partially by lyophilization, and finally dialyzed twice against 2 liters of double-distilled water and used as the elicitor source. Soluble sugars were quantified by the anthrone method as a parameter for elicitor concentrations.

$\mathrm{H}_{2} \mathrm{O}_{2}$ determination by spectrofluorimeter and diaminobenzidine. $\mathrm{H}_{2} \mathrm{O}_{2}$ production in cultured avocado cells was measured by monitoring the scopoletin conversion to nonfluorescent product (47). The cell suspensions were washed twice with a medium containing $2 \%$ sucrose, $1 \mathrm{mM} \mathrm{NaH} \mathrm{PO}_{4}, 1 \mathrm{mM}\left(\mathrm{NH}_{4}\right)_{2} \mathrm{SO}_{4}, 1 \mathrm{mM} \mathrm{MgSO}$, $1 \mathrm{mM} \mathrm{CaCl}_{2}, 25 \mathrm{mM} \mathrm{KNO}_{3}$, and $20 \mathrm{mM}$ 2-( $N$-morpholino)ethanesulfonic acid (MES) adjusted to $\mathrm{pH}$ 6.6. The cells were concentrated to $10^{6}$ cells per $\mathrm{ml}$ with washing medium. The cells were allowed to stand for $0.5 \mathrm{~h}$ at room temperature, $200 \mu \mathrm{l}$ of cell suspensions were placed in enzyme-linked immunosorbent assay plates, and $0.1 \mathrm{mM}$ scopoletin $(10 \mu \mathrm{l})$ and $30 \mu \mathrm{M}$ horseradish peroxidase $(10 \mu \mathrm{l})$ were

TABLE 1. Effect of cell wall extract from Colletotrichum gloeosporioides on reactive oxygen species production in avocado cell suspensions

\begin{tabular}{|c|c|c|c|}
\hline & \multicolumn{3}{|c|}{ Cytochrome $c$ reduction $(\mu \mathrm{mol})^{\mathrm{a}}$} \\
\hline & $30 \mathrm{~min}$ & $60 \mathrm{~min}$ & $120 \mathrm{~min}$ \\
\hline Elicitor $(15$ & 0.00 & $0.34 \pm 0.06$ & $0.91 \pm 0.21$ \\
\hline Elicitor ( $30 \mu \mathrm{g}$ /equivalent Glu) & 0.00 & $0.84 \pm 0.25$ & $2.11 \pm 0.48$ \\
\hline Ionophore $\mathrm{A}-23187^{\mathrm{b}}(1 \mu \mathrm{M})$ & $1.14 \pm 0.019$ & NT & NT \\
\hline
\end{tabular}

a The difference in cytochrome $c$ reduction $\Delta_{\mathrm{OD}(530-570)}$ in the absence and presence of superoxide dismutase is used as a measurement of $\mathrm{O}_{2}^{-}$production, since each $\mathrm{O}_{2}^{-}$reduces ferric cytochrome $c$ to its ferrous form (33). Cytochrome $c$ reduction was measured in $10^{6}$ avocado cells. Means and standard errors are based on the data from one experiment of four that gave similar results. Each treatment was replicated five times. NT $=$ not tested.

b The ionophore A-23187 was used to test the capability of the avocado cell suspensions to release reactive oxygen species. 
added. When fluorescence values had stabilized (5 to $10 \mathrm{~min}$ ), the stimulus was added. The effect of specific inhibitors was tested by adding the inhibitors $5 \mathrm{~min}$ before the addition of the stimulus. Staurosporine, K-252a, and microcystin-LR were added from stock solutions prepared in dimethyl sulfoxide (DMSO). A similar amount of DMSO was added to the control treatment. The optimal inhibitor's concentration was determined by testing a series of concentrations. Higher concentration of the inhibitor did not further decrease the $\mathrm{H}_{2} \mathrm{O}_{2}$ production by avocado cell suspensions. Oxidation of scopoletin by $\mathrm{H}_{2} \mathrm{O}_{2}$, catalyzed by peroxidase, was measured as the decrease in fluorescence recorded by an automatic reading Microplate-Fluorometer-FLUOstar (BMG Labtechnologies, Offenburg, Germany). The sample was excited at $350 \mathrm{~nm}$ and the emission measured at $460 \mathrm{~nm}$. The fluorometric units were calculated according to the standard curve of $\mathrm{H}_{2} \mathrm{O}_{2}$ concentrations.

For in vivo ROS production, disks of pericarp tissue $(1 \mathrm{~cm}$ in diameter) were placed in 3,3'-diaminobenzidine (DAB; Sigma Chemical Co.) solution containing $0.2 \mathrm{mM} \mathrm{CaSO}_{4}$ according to ThordalChristensen et al. (52). ROS generated in the tissue reacted with $\mathrm{DAB}$, resulting in a dark brown pericarp. At various times after inoculation, transferring the disks to $20 \mathrm{ml}$ of $96 \%$ ethanol stopped the reaction. The tissue was boiled and the metric lightness units were determined with a Minolta Chroma Meters (CR-200; Minolta Camera, Ltd., Osaka, Japan). Maximal value of metric lightness (45 units) was obtained in the untreated control tissue. Disks of pericarp placed in DAB solution treated with increasing concentrations of $\mathrm{H}_{2} \mathrm{O}_{2}$ ( 0 to $\left.50 \mathrm{mM}\right)$ resulted in darker tissue and a reduction of lightness units (the value with $50 \mathrm{mM}$ was 31 units). The regression coefficient between $\mathrm{H}_{2} \mathrm{O}_{2}$ concentrations ( 0 to $50 \mathrm{mM}$ ) and the units of lightness was $r=0.934$. Similar regression coefficients were obtained in three independent experiments.

Preparation of microsomes and isolation of plasma membranes. Plasma membranes were isolated from $40 \mathrm{~g}$ of pericarp strips after treatment with $0.2 \mathrm{mM} \mathrm{CaSO}_{4}$ for $24 \mathrm{~h}$, as described above. Plasma membrane was isolated at several periods after inoculation with $C$. gloeosporioides. Tissue was homogenized in a Waring blender (Waring Products, New Hartford, CT) at $4^{\circ} \mathrm{C}$, and the microsomes were prepared according to Giannini et al. (16). The microsomes were suspended in suspension medium $(330 \mathrm{mM}$ sucrose, $5 \mathrm{mM} \mathrm{KCl}$, and $5 \mathrm{mM}$ potassium phosphate buffer, $\mathrm{pH} 7.8$ ), and the plasma membranes were separated by two-phase partitioning (26). The final composition of the phase system was $6.4 \%$ (wt/wt) of each of dextran T500 and polyethylene glycol (PEG 3350) in the suspension medium. The final upper phase was diluted

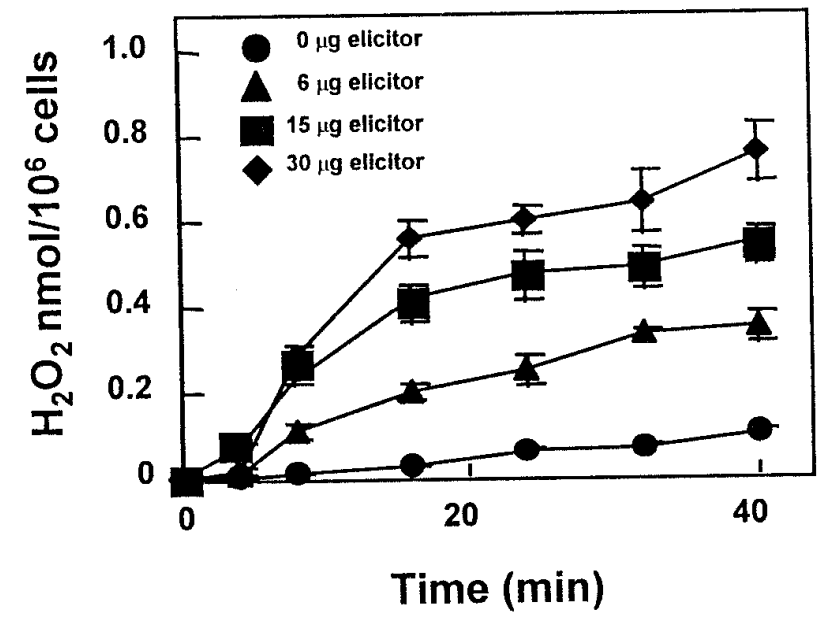

Fig. 2. Effect of Colletotrichum gloeosporioides elicitor on the release of $\mathrm{H}_{2} \mathrm{O}_{2}$ from avocado cell suspensions. Different concentrations of elicitor were added to the avocado cell suspensions $\left(10^{6}\right.$ cells $)$ and their effects were compared with that of the untreated control. Bars represent standard errors. The data from four experiments with three replications per treatment were pooled.
1:10 with resuspension medium/330 $\mathrm{mM}$ sucrose, $1 \mathrm{mM}$ dithiothreitol (DTT), $5 \mathrm{mM} \mathrm{NaF}$, and $5 \mathrm{mM}$ MES-bis-tris propane (MES-BTP), $\mathrm{pH} 7.8$, and the purified plasma membranes were pelted at 55,000 $\times g$. The pellet was redissolved and brought to a concentration of 1 to $3 \mathrm{mg}$ of protein per $\mathrm{ml}$ and adjusted to $\mathrm{pH} 7.0$ with $330 \mathrm{mM}$ sucrose, $5 \mathrm{mM}$ MES-BTP, and $1 \mathrm{mM}$ DTT. Protein was assayed according to Bradford (8). ATPase activity in these plasma membranes was about $87 \%$ vanadate sensitive.

ROS production measured by cytochrome $c$-reducing activity. ROS production was determined by cytochrome $c$ reduction dependent on NADPH oxidation according to Owen and Hancock (36). By this method, for each molecule of ROS production, one molecule of cytochrome $c$ reduction is detected (33). The assay consisted of $20 \mu \mathrm{M}$ cytochrome $c$ (Sigma type VI; Sigma Chemical Co.), $100 \mu \mathrm{M}$ NADPH, $25 \mathrm{mM}$ potassium phosphate buffer ( $\mathrm{pH} 7.5$ ), and $10 \mu \mathrm{g}$ of plasma membrane protein in a total volume of $1 \mathrm{ml}$. The reaction was started with the addition of NADPH, and the rate of cytochrome $c$ reduction was measured on a dual-wavelength spectrophotometer at $550 \mathrm{~nm}$ by the difference in the absence and presence of $100 \mu \mathrm{g}$ of superoxide dismutase $(14,36)$.

\section{RESULTS}

ROS production in avocado fruit tissue triggered by fungal infection and fungal cell wall elicitor. Plasma membranes of isolated pericarp tissue that had been preinoculated with C. gloeosporioides showed a rapid increase in superoxide production, measured by cytochrome $c$ reduction. ROS production by the isolated plasma membrane of inoculated pericarp from unripe avocado fruits increased by threefold within $1 \mathrm{~h}$ and remained higher up to $4 \mathrm{~h}$ after inoculation compared with that of the uninoculated pericarp tissue (Fig. 1). Addition of fungal cell wall elicitor to avocado cell suspensions enhanced the cytochrome $c$ reduction within $1 \mathrm{~h}$ after treatment (Table 1).

$\mathrm{H}_{2} \mathrm{O}_{2}$ production in unripe avocado fruit tissue elicited by direct fungal infection and fungal cell wall elicitor. ROS was initially detected by DAB staining $2 \mathrm{~h}$ after unripe avocado pericarp was inoculated with $C$. gloeosporioides. Avocado pericarp inoculated with $C$. gloeosporioides at 0 time showed $42.7 \pm 2.3$ metric lightness units, and $2 \mathrm{~h}$ later, it decreased to $40.1 \pm 1.3$ units. The lightness further decreased to $37.8 \pm 2.8$ and $35.6 \pm 1.3$ units, 10 and $20 \mathrm{~h}$ after inoculation, respectively. When cultured avocado cell suspensions were treated with cell wall elicitor $(6 \mu \mathrm{g}$ of glucose equivalents), release of $\mathrm{H}_{2} \mathrm{O}_{2}$ was detected within a few minutes, as determined by the loss of scopoletin fluorescence (Fig. 2). Increasing amounts of elicitor ( 15 and $30 \mu \mathrm{g}$ of glucose equivalents) further increased the generation of $\mathrm{H}_{2} \mathrm{O}_{2}$ by the avocado cell cultures.

Effect of protein kinase and phosphatase inhibitors on $\mathrm{H}_{2} \mathrm{O}_{2}$ release by avocado cell suspension system treated with fungal cell wall elicitor. Incubation of cultured avocado cells in the presence of protein kinase inhibitor, such as K-252a (1 $\mu \mathrm{M})$ and staurosporine $(10 \mu \mathrm{M})$, inhibited $\mathrm{H}_{2} \mathrm{O}_{2}$ release by 70 to $94 \%$ (Table 2).

TABLE 2. Effect of cell wall extract from Colletotrichum gloeosporioides on the release of $\mathrm{H}_{2} \mathrm{O}_{2}$ from avocado cell suspensions ${ }^{\mathrm{a}}$

\begin{tabular}{ll}
\hline & $\mathrm{H}_{2} \mathrm{O}_{2}(\mathrm{nmol}) \pm \mathrm{SE}$ \\
\hline Cells only & $0.14 \pm 0.022$ \\
Elicitor $(60 \mu \mathrm{g} /$ /equivalent Glu $)$ & $1.01 \pm 0.26$ \\
Staurosporine $(10 \mu \mathrm{M})+$ elicitor & $0.306 \pm 0.092$ \\
$\mathrm{~K}-252 \mathrm{a}(1 \mu \mathrm{M})+$ elicitor & $0.15 \pm 0.068$ \\
Microcystin-LR $(1 \mu \mathrm{M})+$ elicitor & $0.254 \pm 0.076$ \\
Ionophore A23187 $(5 \mu \mathrm{M})$ & $2.87 \pm 0.402$ \\
\hline
\end{tabular}

${ }^{a}$ Cell wall elicitor from $C$. gloeosporioides prepared as described in text. Release of $\mathrm{H}_{2} \mathrm{O}_{2}$ from suspensions of $10^{6}$ avocado cells within $10 \mathrm{~min}$ after adding elicitor and various inhibitors. The release of $\mathrm{H}_{2} \mathrm{O}$ was measured as oxidation of scopoletin $350 / 460 \mathrm{~nm}$ in the presence of peroxidase. Means and standard errors (SE) are based on the results of one experiment of four that gave similar results. Each treatment was replicated three times. 
The phosphatase inhibitor microcystin-LR $(1 \mu \mathrm{M})$ also inhibited $\mathrm{H}_{2} \mathrm{O}_{2}$ release by $75 \%$. While the $\mathrm{Ca}^{2+}$ ionophore A-23187 alone stimulated the release of $\mathrm{H}_{2} \mathrm{O}_{2}$ from cultured avocado cells almost threefold.

Effects of challenge inoculation of $C$. gloeosporioides and $\mathrm{H}_{2} \mathrm{O}_{2}$ on enhancement of epicatechin, PAL, and ROS production. Early reports showed that challenge inoculation of whole avocado fruits enhanced the level of epicatechin and the activity of PAL in the fruit pericarp within $24 \mathrm{~h}(2,42)$. Inoculation of pericarp tissue from unripe avocado fruits with $C$. gloeosporioides increased the epicatechin level by twofold within $6 \mathrm{~h}$ (Fig. 3). During the same period, PAL activity increased as measured by the increment of cinnamic acid from 3.5 to $6 \mu \mathrm{mol}$ per $\mathrm{mg}$ of protein per h (data not shown).

Treatment of pericarp tissue (unripe avocado fruits) with exogenous $\mathrm{H}_{2} \mathrm{O}_{2}(1 \mathrm{mM})$ doubled ROS production by the plasma membrane within 30 min (Fig. 4). $\mathrm{H}_{2} \mathrm{O}_{2}$ treatment induced a 1.5-fold increase in PAL activity within $60 \mathrm{~min}$ and a 2.5 -fold increase $6 \mathrm{~h}$ after treatment (Fig. 5B). A similar pattern of increase was observed in the epicatechin level, which increased from an initial value of 400 to $1,200 \mu \mathrm{g} / \mathrm{g}$ fresh weight $6 \mathrm{~h}$ after treatment (Fig. 5A). Treat-

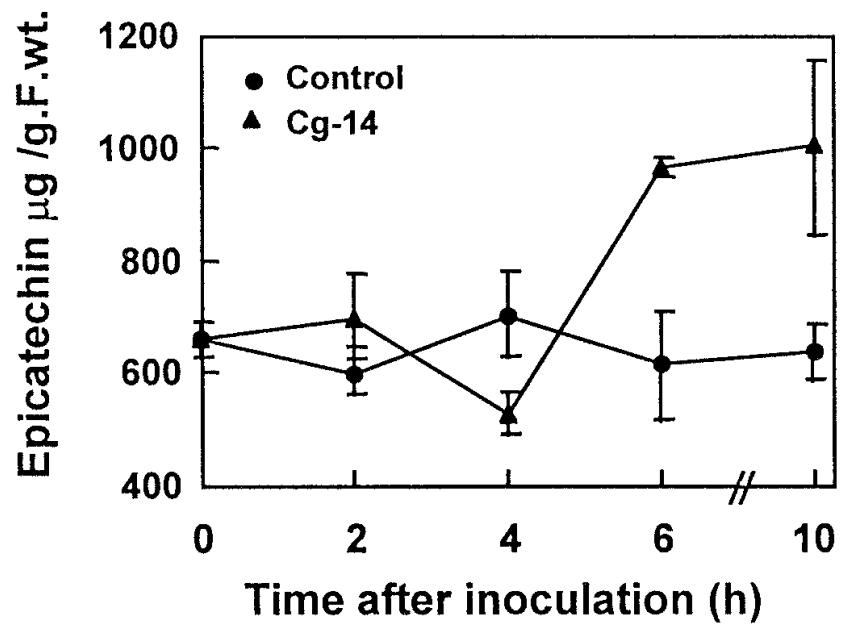

Fig. 3. Epicatechin levels in avocado fruit pericarp (unripe) in response to inoculation with Colletotrichum gloeosporioides strain Cg-14. Pericarp was sampled from freshly harvested fruits, incubated for $24 \mathrm{~h}$ in an aerated solution of $0.2 \mathrm{mM} \mathrm{CaSO}_{4}$, and then inoculated as described in text. Bars represent standard errors. The data from three experiments with three replications per treatment were pooled.

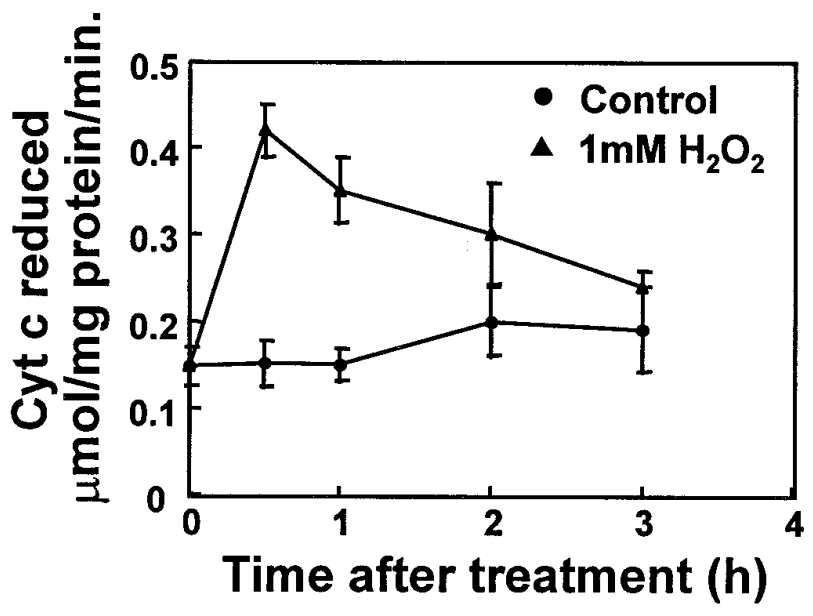

Fig. 4. Time course of reactive oxygen species production in plasma membrane isolated from unripe pericarp tissue treated with $1 \mathrm{mM} \mathrm{H}_{2} \mathrm{O}_{2}$. Bars represent standard errors from one representative experiment run four times with three replications. ment of pericarp tissue with $5 \mathrm{mM} \mathrm{H}_{2} \mathrm{O}_{2}$ induced faster increases in PAL activity and epicatechin levels than did $1 \mathrm{mM} \mathrm{H}_{2} \mathrm{O}_{2} 1 \mathrm{~h}$ after treatment. However, PAL activity and epicatechin levels in the $5 \mathrm{mM} \mathrm{H}_{2} \mathrm{O}_{2}$ exogenously treated pericarp started to declined $1 \mathrm{~h}$ after treatment, while at $1 \mathrm{mM} \mathrm{H}_{2} \mathrm{O}_{2}$, the activity increased continuously during the $5 \mathrm{~h}$ following treatment. When avocado pericarp was treated with $1 \mu \mathrm{M}$ staurosporine by brushing the pericarp $20 \mathrm{~min}$ before its exposure to $1 \mathrm{mM} \mathrm{H}_{2} \mathrm{O}_{2}$, PAL activity was inhibited and was similar to that found in untreated pericarp tissue (Fig. 6).

ROS production in pericarp of unripe, resistant and of ripe, susceptible avocado fruits. ROS levels in uninoculated plasma membranes from pericarp of unripe, resistant fruits was 2.3-fold higher than ROS production in ripe, susceptible fruits (Fig. 7). Inoculation of pericarp in resistant fruits showed that ROS levels in the resistant tissue was 4.3-fold higher than in ripe fruits (Fig. 7).

\section{DISCUSSION}

ROS produced in response to pathogen attack or elicitor treatment have been hypothesized to have direct antimicrobial effects and play a role in defense mechanisms by triggering lignin accumulation, lipid peroxidation, phytoalexin production, and the hypersensitive response (5). One of the probable sources of ROS induced by early interactions with fungal infection is NADPH oxidase located in the plasma membranes (45). In our experiments, $C$. gloeosporioides infection activated the production of ROS threefold in plasma membranes of avocado pericarp within $1 \mathrm{~h}$ after inoculation. Production of ROS was also detected in cultured avocado cells $8 \mathrm{~min}$ after treatment with cell wall elicitor prepared from C. gloeosporioides. Production of ROS is, thus, one of the most rapid biochemical responses detected in avocado pericarp tissue $(1,14)$.

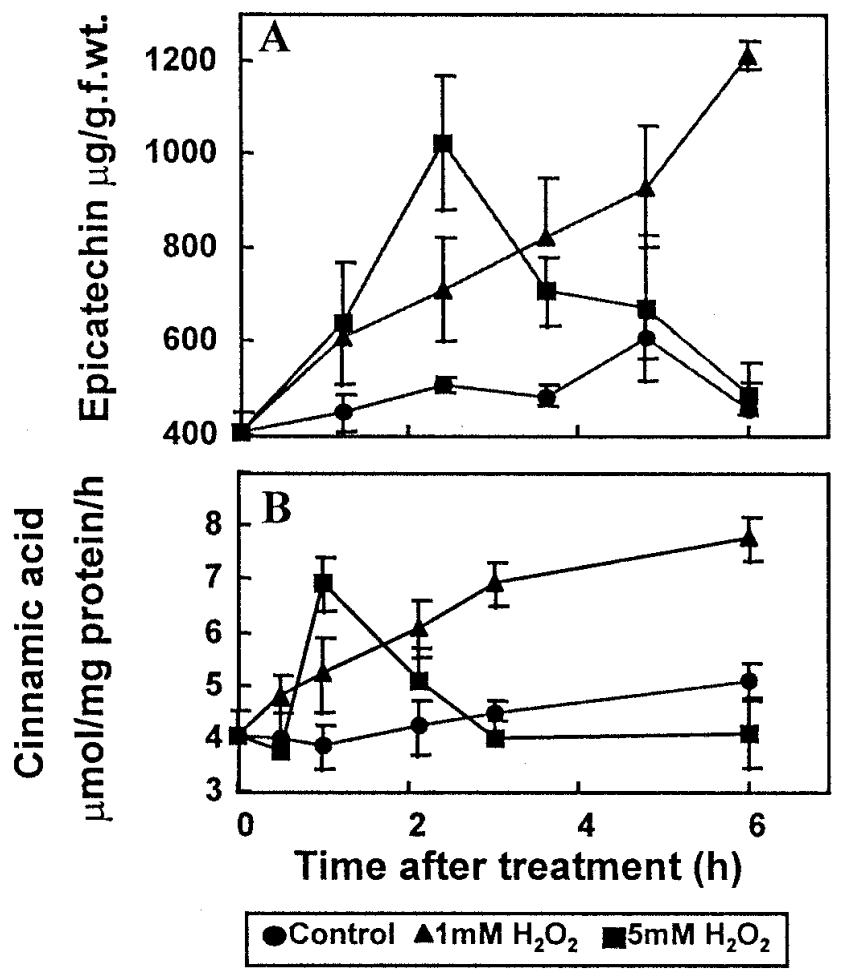

Fig. 5. Epicatechin levels and phenylalanine ammonia lyase (PAL) activity in the pericarp of unripe avocado fruit cv. Fuerte treated with $\mathrm{H}_{2} \mathrm{O}_{2}$. Pericarp was sampled from freshly harvested fruits, incubated in an aerated solution of $0.2 \mathrm{mM} \mathrm{CaSO}_{4}$ for $24 \mathrm{~h}$, and then treated with $\mathrm{H}_{2} \mathrm{O}_{2}$ as described in text. A, Epicatechin levels, and B, PAL activity. Bars represent standard errors. The data from three experiments with five replications per treatment were pooled. 
Programmed cell death induced by $\mathrm{H}_{2} \mathrm{O}_{2}$ has been reported in several plant systems $(20,28)$. However, in the current study, no obvious cell death was observed in the avocado pericarp tissue or in cultured avocado cells where ROS production was detected. $\mathrm{H}_{2} \mathrm{O}_{2}$ was easily detected in cultured avocado cells, as reported for other cell suspension systems $(29,49)$. Eight minutes after cultured avocado suspension cells were exposed to the cell wall elicitor of C. gloeosporioides, a 10-fold increase in $\mathrm{H}_{2} \mathrm{O}_{2}$ production was observed. In inoculated pericarp, however, release of ROS was detected by DAB staining only after several hours. It might be possible that the delay in $\mathrm{H}_{2} \mathrm{O}_{2}$ detection in tissue is a result of partial destruction of the generated ROS, since significant activities of catalase and peroxidase are found in the avocado pericarp (D. Beno-Moualem and D. Prusky, unpublished data).

The ability of the cell wall elicitor to enhance $\mathrm{H}_{2} \mathrm{O}_{2}$ release in a cultured avocado cell suspension system is promoted by the rapid binding to, or interaction with, the plasma membrane. Binding of several oligo- or polyglucans from fungal origin to soybean microsomal membranes has been reported $(10,11)$. Avocado fruit pericarp, similar to other plant organs (34), might recognize the pathogen or the cell wall elicitors at very early stages in the infection process and react with rapid generation of ROS. These findings imply that the plasma membranes of avocado fruit pericarp acts as a site for the initial binding of elicitor molecules that triggers the defense response (42). In previous work, it was found that influx of $\mathrm{Ca}^{2+}$, exchange of $\mathrm{H}^{+} / \mathrm{K}^{+}$across the cell membrane, and activation of ion channels occurred within $10 \mathrm{~min}$ after elicitor treatment, before ROS were released (35). We demonstrated here that the avocado cell suspensions could be activated to generate $\mathrm{H}_{2} \mathrm{O}_{2}$ by the addition of the $\mathrm{Ca}^{2+}$ ionophore A-23187, which allows the influx of the $\mathrm{Ca}^{2+}$ ions. In other systems in which specific elicitors were used, increased endogenic $\mathrm{Ca}^{2+}$ also was found to stimulate the release of $\mathrm{H}_{2} \mathrm{O}_{2}(21,35,49)$. Additionally, protein kinase inhibitors such as staurosporine and $\mathrm{K}-252 \mathrm{a}$ significantly reduced ROS production in cultured avocado cell suspensions induced by the Colletotrichum cell wall. The phosphatase inhibitor microcystinLR also inhibited ROS production. From the action of kinase and phosphatase inhibitors, one can deduce that different processes (phosphorylation and dephosphorylation) might regulate the induction of ROS in avocado fruit tissue.

Prusky et al. (39) reported that challenge inoculation of intact fruits with pathogenic or nonpathogenic Colletotrichum strains enhanced PAL activity and other phenylpropanoid biosynthetic en-

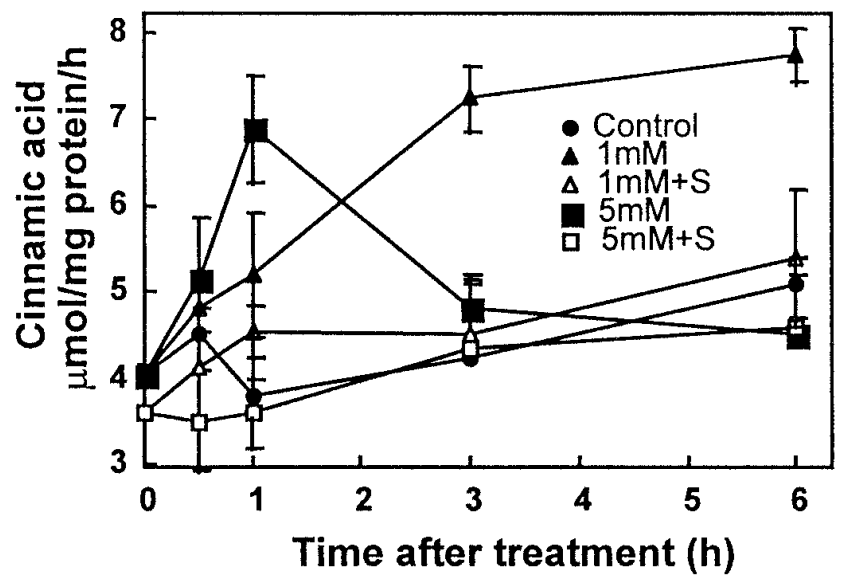

Fig. 6. Effect of staurosporine on the activity of PAL, induced by $\mathrm{H}_{2} \mathrm{O}_{2}$, in isolated pericarp tissue of unripe avocado fruits. Pericarp tissue was sampled from freshly harvested fruits and incubated in an aerated solution of $0.2 \mathrm{mM}$ $\mathrm{CaSO}_{4}$ for $24 \mathrm{~h}$. The pericarp was brushed four times during 20 min with $1 \mu \mathrm{M}$ staurosporine $(\mathrm{S})$, followed by treatment with $1 \mathrm{mM}$ and $5 \mathrm{mM} \mathrm{H}_{2} \mathrm{O}_{2}$. Bars represent standard errors. The data from three experiments with three replications per treatment were pooled. zymes within 24 h. Following the early reports of Doke (14), the connection between ROS production and phytoalexin synthesis has been explored in several interactions $(1,12,25,46)$. Apostol et al. (1) reported that exogenous $\mathrm{H}_{2} \mathrm{O}_{2}(0.5$ to $1 \mathrm{mM})$ added to soybean suspension cells was sufficient to induce glyceollin. In this work, we found that avocado fruit, similar to other plant organs, increased ROS production, PAL activity, and epicatechin levels after fungal inoculation. We found that application of exogenic $\mathrm{H}_{2} \mathrm{O}_{2}$ to pericarp tissue also induced an increase of the epicatechin level, which indicates that the reactive oxygen level produced during the Colletotrichum-avocado interaction leads to the activation of phenylpropanoid pathway. However, inhibition of this process by pretreatment of pericarp with staurosporine before $\mathrm{H}_{2} \mathrm{O}_{2}$ application inhibited PAL activity, suggesting that protein kinase activity is required for the activation of phenylpropanoid biosynthesis in the avocado system. It is possible that the application of $\mathrm{H}_{2} \mathrm{O}_{2}$ may trigger a second oxidative burst as shown by Park et al. (37) in potato slices. In their system also, staurosporine inhibited the induction of subsystemic oxidative burst by $\mathrm{H}_{2} \mathrm{O}_{2}$. This might indicate that $\mathrm{H}_{2} \mathrm{O}_{2}$ stimulates a novel secondary signaling process in avocado tissue.

The production of ROS in avocado fruit is reported, for the first time, to depend on the physiological stage of fruit ripening. In pericarp of freshly harvested unripe, resistant fruits, ROS production was $0.168 \pm 0.026$ compared with only $0.072 \pm$ $0.014 \mu \mathrm{mol}$ of cytochrome $c$ per $\mathrm{mg}$ of protein per min in the ripe, susceptible tissue. It is possible that one of the factors affecting the induction of resistance in unripe fruit is the capability to react and the presence of naturally high ROS levels, compared with the reduced capability to react in ripe fruits $(40,41)$. Induction of $\mathrm{H}_{2} \mathrm{O}_{2}$ production has been described in parsley cell suspensions and cucumber, in which the response can be further enhanced by 2,6-dichloroisonicotinic acid, salicylic acid, or methyl jasmonate, and also by cuticle abrasion (15). In avocado fruit, $C$. gloeosporioides spores that land on the fruit cuticle germinate within a few hours and produce appressoria from which penetration hyphae breach the fruit cuticle. We hypothesize that the infection point will subsequently become the local source for ROS production that will activate the phenylpropanoid pathway, preserve or increase the levels of the antifungal compound diene, and ultimately inhibit fungal development, resulting in its quiescence (2).

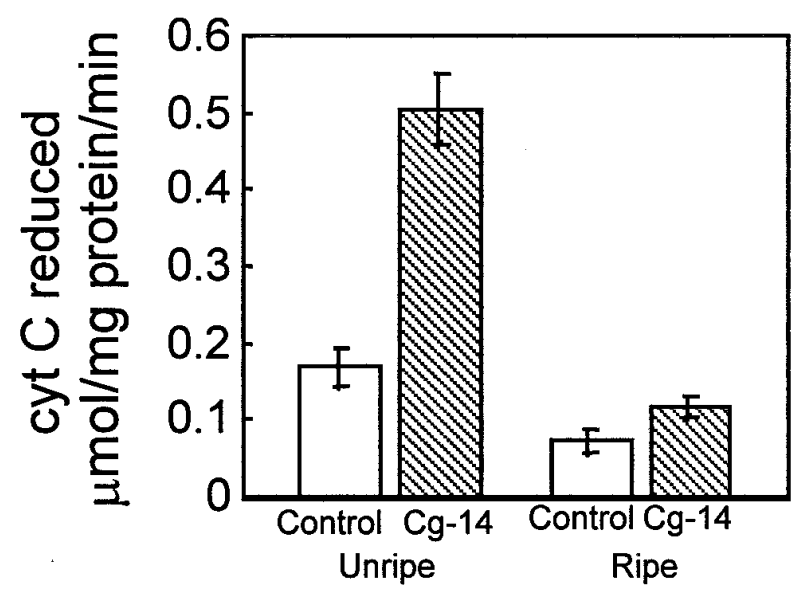

Fig. 7. Reactive oxygen species production in plasma membrane isolated from pericarp of unripe, resistant fruits and of ripe, susceptible fruits. The resistant fruits and the susceptible fruits were harvested on the same day. The susceptible fruit were stored for 12 days to ripen completely and become soft. Both pericarp tissues were inoculated with Colletotrichum gloeosporioides strain $\mathrm{Cg}-14$. Activity was tested $4 \mathrm{~h}$ after inoculation, at the same time as was noninoculated fruit. Bars represent standard errors. The data from four experiments with five replications per treatment were pooled. 


\section{ACKNOWLEDGMENTS}

We thank BARD, GIARA, and CDR-AID for the financial support granted to D. Prusky. Contribution from the Agricultural Research Organization, The Volcani Center, P.O. Box 6, Bet Dagan 20125, Israel.

\section{LITERATURE CITED}

1. Apostol, I., Hienstein, P. F., and Low, P. S. 1989. Rapid stimulation of an oxidative burst during elicitation of cultured plant cells. Plant Physiol. 90:109-116.

2. Ardi, R., Kobiler, I., Keen, N. T., and Prusky, D. 1998. Involvement of epicatechin biosynthesis in the resistance of avocado fruits to postharvest decay. Physiol. Mol. Plant Pathol. 53:269-285.

3. Auh, C. K., and Murphy, T. M. 1995. Plasma membrane redox enzyme is involved in the synthesis of $\mathrm{O}_{2}$ and $\mathrm{H}_{2} \mathrm{O}_{2}$ by Phytophthora elicitorstimulated in the synthesis rose cells. Plant Physiol. 107:1241-1247.

4. Ayers, A. R., Ebel, J., Valent, B., and Albersheim, P. 1976. Host pathogen interactions. X. Fractionation and biological activity of an elicitor isolated from the mycelial walls of Phytophthora megasperma var. sojae. Plant Physiol. 57:760-765.

5. Baker, C. J., and Orlandi, E. W. 1995. Active oxygen in plant pathogenesis. Annu. Rev. Phytopathol. 33:299-322.

6. Bartnicki-Garcia, S., Bracker, C. E., Reyes, E., and Ruiz-Herrera, J. 1978. Isolation of chitosomes from taxonomically diverse fungi and synthesis of chitin microfibrils in vitro. Exp. Mycol. 2:173-192.

7. Bottini, A., Vernoesi, C., Pontier, D., Esquerre-Tugaye, M. T., Beliin, J. P., Rusterucci, C., and Ricci, P. 1994. Differential responses of tobacco cells to elicitors from two Phytophthora species. Plant Physiol. Biochem. 32:373-378

8. Bradford, M. M. 1976. A rapid and sensitive method for the quantitation of microgram quantities of protein utilizing the principle of protein-dye binding. Anal. Biochem. 72:248-254.

9. Bradley, D. J., Kjellbom, P., and Lamb, C. J. 1992. Elicitor-induced and wound-induced oxidative cross-linking of a proline-rich plant cell wall protein-A novel, rapid defense response. Cell 70:21-30.

10. Cheong, J. J., and Hahn, M. 1991. A specific high-affinity binding site for the hepta-b-glucoside elicitor exists in soybean membranes. Plant Cell 3:137-147.

11. Cosio, E. G., Frey, T., and Ebel, J. 1990. Solubilization and characteristics of the binding sites for fungal b-glucans from soybean cell membranes. FEBS (Fed. Eur. Biochem. Soc.) Lett. 264:235-238.

12. Devlin, W. S., and Gustine, D. L. 1992. Involvement of the oxidative burst in phytoalexin accumulation and the hypersensitive reaction. Plant Physiol. 100:1189-1195.

13. Doke, N. 1983. Generation of superoxide anion by potato tuber protoplasts upon the hypersensitive response to hyphal wall components of Phytophthora infestans and specific inhibition of the reaction by suppressors of hypersensitivity. Physiol. Plant Pathol. 23:359-367.

14. Doke, N. 1985. NADPH-dependent $\mathrm{O}_{2}^{-}$generation in membrane fractions isolated from wounded potato tubers inoculated with Phytophthora infestans and to the hyphal wall components. Physiol. Plant Pathol. 27: 311-357.

15. Fauth, M., Merten, A., Hahn, M. G., Jeblick, W., and Kauss, H. 1996. Competence for elicitation of $\mathrm{H}_{2} \mathrm{O}_{2}$ in hypocotyls of cucumber is induced by breaching the cuticle and is enhanced by salicylic acid. Plant Physiol. 110:347-354

16. Giannini, J. L., Gildensoph, L. H., and Briskin, D. P. 1987. Selective production of sealed plasma membrane vesicles from red beet (Beta vulgaris L.) storage tissue. Arch. Biochem. Biophys. 254:621-630.

17. Grabov, A., and Bottger, M. 1994. Are redox reactions involved in regulation of $\mathrm{K}+$ channels in the plasma membrane of Limnobium stoloniferum root hairs? Plant Physiol. 105:927-935.

18. Guern, J., Mathieu, G., Ephritikhine, C. I., Luttge, U., Marre, M. T., and Marre, E. 1988. Intracellular $\mathrm{pH}$ modification linked to the activity of the ferricyanide driven activity of the plasmalemma redox system in Elodea densa leaves, Acer pseudoplatanus and Catharanthus roseus cells. Page 412 in: Plasma Membrane Oxidoreductases in Control of Animal and Plant Growth, Life Sciences, Vol. 157. F. L. Crane, D. J. Morre, and H. Low, eds. Plenum Publishing, New York.

19. Hammerschmidt, R., and Kuć, J. 1982. Lignification as a mechanism for induced systemic resistance in cucumber. Physiol. Plant Pathol. 20:61-71.

20. Harding, S. A., and Roberts, D. M. 1998. Incompatible pathogen infection results in enhanced reactive oxygen and cell death responses in transgenic expressing a hyperactive mutant calmodulin. Planta 206:253-258.

21. He, S. Y., Huang, H. C., and Collmer, A. 1993. Pseudomonas syringae pv. syringae harpin Pss: A protein that is secreted via the hrp pathway and elicits the hypersensitive response in plants. Cell 73:1-20.

22. Karni, L., Prusky, D., Kobiler, I., Bar-Shira, E., and Kobiler, D. 1989.
Involvement of epicatechin in the regulation of lipoxygenase activity during activation of quiescent Colletotrichum gloeosporioides infections of ripening avocado fruits. Physiol. Mol. Plant Pathol. 35:367-374.

23. Keppler, L. D., and Novacky, A. 1987. The initiation of lipid peroxidation during bacteria-induced hypersensitive reaction. Physiol. Mol. Plant Pathol. 30:233-245.

24. Kohle, H., Young, D. H., and Kauss, H. 1984. Physiological changes in suspension cultured soybean cells elicited by treatment with chitosan. Plant Sci. 33:221-230.

25. Kondo, Y., Hanawa, F., Miyazawa, T., and Mizutani, J. 1993. Detection of rapid and transient generation of activated oxygen and phospholipid hydroperoxide in soybean after treatment with fungal elicitor by chemiluminescence assay. Pages 148-151 in: Mechanisms of Plant Defense Responses. B. Fritig and M. Legrand, eds. Kluwer, Dordrecht, the Netherlands.

26. Larsson, C., Widell, S., and Kjellbom, P. 1987. Preparation of high purity plasma membranes. Methods Enzymol. 148:558-568.

27. Leon, J., Lawton, M. A., and Raskin, I. 1995. Hydrogen peroxide stimulates salicylic acid biosynthesis in tobacco. Plant Physiol. 108:1673-1678.

28. Levine, A., Tenhaken, R., Dixon, R., and Lamb, C. $1994 . \mathrm{H}_{2} \mathrm{O}_{2}$ from the oxidative burst orchestrates the plant hypersensitive disease resistance response. Cell 79:583-593.

29. Linder, W. A., Hoffmann, C., and Grisebach, H. 1988. Rapid elicitorinduced chemiluminescence in soybean cell suspension cultures. Phytochemistry 27:2501-2503.

30. Lisker, N., Cohen, L., Chalutz, E., and Fuchs, Y. 1983. Fungal infections suppress ethylene induced phenylalanine ammonia lyase activity in grapefruit. Physiol. Plant Pathol. 22:331-338.

31. Marre, M. T., Moroni, A., Albergoni, F. G., and Marre, E. 1988. Plasmalemma redox activity and $\mathrm{H}^{+}$-extrusion. I. Activation of the $\mathrm{H}^{+}$-pump by ferricyanide-induced potential depolarization and cytoplasm-acidification. Plant Physiol. 87:25-29.

32. Mathieu, Y., Sanchez, F. J., Droillard, M. J., Lapous, D., Lauriere, C., and Guern, J. 1996. Involvement of protein phosphorylation in the early steps of transduction of the oligogalacturonide in tobacco cell signal cells. Plant Physiol. Biochem. 34:399-408.

33. Mayo, L. A., and Curnutte, J. T. 1990. Kinetic icroplate assay for superoxide production by neutrophils and other phagocytic cells. Methods Enzymol. 186:567-575.

34. Mehdy, C. N. 1994. Active oxygen species in plants defense against pathogens. Plant Physiol. 105:467-472.

35. Nurnberger, T., Nennstiel, D., Jabs, T., Sacks, W. R., Hahlbrock, K., and Scheel, D. 1994. High affinity binding of a fungal oligopeptide elicitor to parsley plasma membranes triggers multiple defense responses. Cell 78:449-460.

36. Owen, T. G. J., and Hancock, J. T. 1994. Assays of plasma membrane NADPH oxidase. Methods Enzymol. 186:222-229.

37. Park, H., Miura, Y., Kawakita, K., Yoshioka, H., and Doke, N. 1998. Physiological mechanisms of a sub-systemic oxidative burst triggered by elicitor induced local oxidative burst in potato tuber slices. Plant Cell Physiol. 39(11):1218-1225.

38. Prusky, D. 1996. Quiescent infections by postharvest pathogens. Annu. Rev. Phytopathol. 34:413-434.

39. Prusky, D., Freeman, S., Rodriguez, R. J., and Keen, N. T. 1994. A nonpathogenic mutant strain of Colletotrichum magna induces resistance to C. gloeosporioides in avocado fruits. Mol. Plant-Microbe Interact. 7: 326-333.

40. Prusky, D., Hamdan, H., Ardi, R., and Keen, N. T. 1996. Induction of biosynthesis of the epicatechin in avocado suspension cells treated with an enriched $\mathrm{CO}_{2}$ atmosphere. Physiol. Mol. Plant Pathol. 48:171-178.

41. Prusky, D., Karni, L., Kobiler, I., and Plumbey, R. 1990. Induction of a preformed antifungal compound in unripe fruits: Effect of challenge inoculation with Colletotrichum gloeosporioides. Physiol. Mol. Plant Pathol. 37:425-435.

42. Prusky, D., and Keen, N. T. 1993. Involvement of preformed antifungal compounds in the resistance of subtropical fruits to fungal decay. Plant Dis. 77:114-119.

43. Prusky, D., Keen, N. T., and Eaks, I. 1983. Further evidence for the involvement of a preformed antifungal compound in the latency of $\mathrm{Col}$ letotrichum gloeosporioides on the unripe fruits. Physiol. Plant Pathol. 22:189-198.

44. Prusky, D., Keen, N. T., Sims, J. J., and Midland, S. L. 1982. Possible involvement of an antifungal diene in the latency of Colletotrichum gloeosporioides on unripe avocado fruits. Phytopathology 72:1578-1582.

45. Pugin, A., Frachiesse, J. M., Tavernier, E., Bligny, R., Gout, E., Douce, R., and Guern, J. 1997. Early events induced by the elicitor cryptogein in tobacco cells: Involvement of a plasma membrane NADPH oxidase and activation of glycolysis and the pentose phosphate pathway. Plant Cell 9: 2077-2091.

46. Rogers, K. M., Albert, F., and Anderson, A. J. 1988. Lipid peroxidation 
is a consequence of elicitor activity. Plant Physiol. 86:547-553.

47. Root, R. K., Metcalf, J., Oshino, N., and Chance, B. 1975. $\mathrm{H}_{2} \mathrm{O}_{2}$ release from human granulocytes during phagocytosis. I. Documentation, quantitation, and some regulating factors. J. Clin. Invest. 55:945-955.

48. Rubinstein, B., and Stern, A. 1986. Relationship of transplasmalemma redox activity to proton and solute transport by roots of Zea mays. Plant Physiol. 80:805-811.

49. Schwacke, R., and Hager, A. 1992. Fungal elicitors induce a transient release of active oxygen species from cultured spruce cells that is dependent on $\mathrm{Ca}^{++}$and protein-kinase activity. Planta 187:136-141.

50. Sutherland, M. W. 1991. The generation of oxygen radicals during host plant responses to infection. Physiol. Mol. Plant Pathol. 39:79-93.
51. Tavernier, E., Wendehenne, D., Blein, J. P., and Pugin, A. 1995. Involvement of free calcium in action of cryptogein, a proteinaceous elicitor of hypersensitive reaction in tobacco cells. Plant Physiol. 109:1025-1031.

52. Thordal-Christensen, H., Zhang, Z., Wei, Y., and Collinge, D. B. 1997. Subcellular localization of $\mathrm{H}_{2} \mathrm{O}_{2}$ in plants. $\mathrm{H}_{2} \mathrm{O}_{2}$ accumulation in papillae and hypersensitive response during the barley-powdery mildew interaction. Plant J. 11:1187-1194.

53. Vera-Estrella, R., Blumwald, E., and Higgins, V. J. 1993. Non-specific glycopeptide elicitors of Cladosporium fulvum. Evidence for involvement of active oxygen species in elicitor-induced effects on tomato cell suspension. Physiol. Mol. Plant Pathol. 42:9-22. 